\title{
Jaguarundi (Puma yagouaroundi) (Geoffroy, 1803) (Carnivora, Felidae) food habits in a mosaic of Atlantic Rainforest and eucalypt plantations of southeastern Brazil
}

\author{
Tófoli, CF. ${ }^{\text {** }}$, Rohe, F. and Setz, EZF.

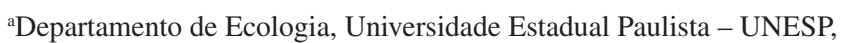 \\ CEP 13506-900, Rio Claro, SP, Brazil \\ ${ }^{\mathrm{b}}$ Departamento de Zoologia, Universidade Estadual de Campinas - UNICAMP, \\ CP 6109, CEP 13083-970, Campinas, SP, Brazil \\ *e-mail: tina@ipe.org.br \\ Received September 24, 2007 - Accepted December 12, 2007 - Accepted Distributed 31, 2009
}

(With 2 figures)

\begin{abstract}
Food habits of jaguarundi (Puma yagouaroundi) (Geoffroy, 1803) (Carnivora, Felidae) were studied between November 2000 and November 2001, in a $24.9 \mathrm{~km}^{2}$ area of secondary Atlantic Rainforest and eucalypt plantation, in the Serra de Paranapiacaba, São Paulo State, Brazil. Analyses of 26 fecal and regurgitate samples, obtained over a stretch of $570.1 \mathrm{~km}$, showed the consumption of 19 prey items and 74 prey occurrences. Small mammals were the most frequent food item $(42.5 \%)$, followed by birds $(21 \%)$, reptiles $(14 \%)$ and medium-sized mammals $(3 \%)$. The percent occurrence (PO) suggests that the diet consisted mainly of small rodents $(30 \%)$ and birds $(21 \%)$. We recorded for the first time the predation of Viperidae snakes by P. yagouaroundi. Although having a large list of items and range of dietary niche breadths $\left(\mathrm{B}_{\text {sta }}=0.76\right.$ ), our data show that jaguarundi prey mainly on small vertebrates (mammals, birds or reptiles), and even in tall tropical forests or eucalypt plantations, it preys mostly on animals that come to, or live on, the ground.
\end{abstract}

Keywords: diet, food habits, jaguarundi, medium-sized carnivores, scat analyses.

\section{Hábitos alimentares do jaguarundi (Puma yagouaroundi) (Carnivora, Felidae) em mosaico de Floresta Atlântica e reflorestamento de eucalipto no sudeste do Brasil}

\begin{abstract}
Resumo
A dieta de uma população de jaguarundi (Puma yagouaroundi) (Geoffroy, 1803) (Carnivora, Felidae) foi estudada entre novembro de 2000 e novembro de 2001, em 24,9 km² de mosaico de Mata Atlântica secundária e reflorestamento de eucalipto na Serra de Paranapiacaba, São Paulo, Brasil. A análise das 26 amostras fecais e regurgitadas, obtidas em $570.1 \mathrm{~km}$ de percurso, indicou o consumo de 19 itens alimentares em um total de 74 ocorrências de presas. Pequenos mamíferos foram os itens mais frequentemente encontrados na dieta (42,5\%), seguidos por aves (21\%), répteis (14\%) e mamíferos de tamanho médio (3\%). A porcentagem de ocorrência (PO) sugere que a dieta concentra-se, principalmente, em pequenos roedores $(30 \%)$ e aves $(21 \%)$. Foi também registrada a predação sobre serpentes da família Viperidae. A amplitude de nicho alimentar padronizada $\left(\mathrm{B}_{\text {sta }}=0,76\right)$ mostra uma dieta generalista, entretanto, os dados sugerem que o jaguarundi consome principalmente pequenos vertebrados (mamíferos, aves ou répteis), sobretudo, espécies terrestres.
\end{abstract}

Palavras-chave: dieta, hábitos alimentares, jaguarundi, carnívoros de médio-porte, análise fecal.

\section{Introduction}

The mesopredator release hypothesis predicted that the decline of large predators would result in the ecological release of mesopredators (small to medium-sized carnivores and omnivores), and that increased predation would result in higher mortality and local extinction rates of some prey species (Fonseca and Robinson, 1990;

Crooks and Soulé, 1999). Large carnivores also play a decisive role in the maintenance of forest biodiversity controlling predation on plants; decreases on top predator populations cause an ecological instability, affecting biodiversity in the ecosystem (Terborgh, 1990; Terborgh et al., 1999; Terborgh et al., 2001). 
Mesopredators can act as a substitute of top predators and produce ripple effects on plant and animal communities (Terborgh et al., 1999), decreasing population densities of small vertebrate prey (Crooks and Soulé, 1999) or indirectly causing important top-down changes in vegetation structure and species diversity (Dirzo and Miranda, 1990). In the studies on Puma yagouaroundi (E. Geoffroy, 1803) (Carnivora, Felidae) food habits it is possible to detect the presence of mesocarnivores, herbivores and/or seed predators (Bisbal, 1986; Mondolfi, 1986; Konecny, 1989; Olmos, 1993; Facure and Giaretta, 1996; Wang, 1999; Guerrero et al., 2002).

Information on jaguarundi ( $P$. yagouaroundi) ecology is scarce. We found eight studies dealing with its diet along its geographical distribution (Konecny, 1989; Bisbal, 1986; Mondolfi, 1986; Olmos, 1993; Manzani and Monteiro-Filho, 1989; Facure and Giaretta, 1996; Wang, 1999; Guerrero et al., 2002). Jaguarundi prey on small and medium sized mammals, birds, snakes, lizards, fishes, invertebrates and eat plant material (Bisbal, 1986; Mondolfi, 1986; Konecny, 1989; Manzani and Monteiro Filho, 1989; Olmos, 1993; Facure and Giaretta, 1996; Wang, 1999; Guerrero, 2002). Cabrera and Yeppes (1940) state that in some regions of Central America primates are its favorite prey, and Ximenes (1982) reported a marmoset Callithrix jacchus (Linnaeus, 1758) (Callitrichidae) in a stomach content from Paraíba, northeast Brazil.

Here we describe the food habits of jaguarundi in a secondary Atlantic Rainforest and mosaic of eucalypt plantation, in southeast Brazil.

\section{Materials and Methods}

This study was conducted at João XXIII Farm (JF) (23 $53^{\circ} 09^{\prime \prime}-23^{\circ} 56^{\prime} 29^{\prime \prime} \mathrm{S}$ and $47^{\circ} 42^{\prime} 30^{\prime \prime}$ $\left.47^{\circ} 40^{\prime} 08^{\prime \prime} \mathrm{W}\right)$, a private property of Eucatex S.A., in the Pilar do Sul municipality, São Paulo State, southeast Brazil, on coastal Atlantic Forest. The area is contiguous to the largest rainforest conservation tract in São Paulo State, which comprises Conservation Units, such as Carlos Botelho, Intervales and Alto Ribeira (PETAR) State Parks. The $24.9 \mathrm{~km}^{2}$ JF comprises $10.5 \mathrm{~km}^{2}$ of secondary dense tropical rainforest, semi-deciduous rainforest and gallery forest, of which $6.1 \mathrm{~km}^{2}$ is continuous forest, $13.1 \mathrm{~km}^{2}$ is Eucalyptus saligna (Smith) (Myrtaceae) plantation, with native understory, and $1.3 \mathrm{~km}^{2}$ is made up of deforested areas. The climate is Cfa (subtropical humid) according to Köppen's classification, with average temperatures around $22{ }^{\circ} \mathrm{C}$ in the hottest month and $15^{\circ} \mathrm{C}$ in the coldest one. Annual rainfall during the study period was $1,722 \mathrm{~mm}$.

Jaguarundi diet was studied by fecal and regurgitation analysis. Monthly, between November 2000 and November 2001, we collected felid scats and regurgitation samples along dirt roads, fire-breakers and trails. Collected scats were stored in plastic bags and dried. In the laboratory, the scats were rinsed with water over a $63 \mu \mathrm{m}$ mesh screen and dried. Hair, bones, teeth, claws, scales, feathers and invertebrate fragments were used for the identification of prey items (Emmons, 1987; Facure and Giaretta, 1996, Guerrero et al., 2002).

Jaguarundi scats were identified as such by its hair ingested while grooming. Under a stereomicroscope, hair microstructure (hair medulla and cuticular scales) was compared to a reference collection from museums (Emmons, 1987; Olmos, 1993; Facure and Giaretta, 1996).

Mammal prey were identified by comparing hair found in the scats with hair and specimens previously collected in the study site and from museums; hair microstructure was also compared. Marsupial teeth were compared to museum specimens; rodents were identified through molar teeth analysis by A. Percequilho, a specialist researcher from MZUSP (University of São Paulo Zoology Museum). Except for one species, bird claws and feet helped identification, by comparison, as Passeriformes and non-passerines. Scales were used to identify reptiles by a specialist.

Scat and regurgitation contents were expressed in terms of frequency of occurrence (FO), the number of times that each item was found divided by the total number of scats, which shows how frequent a species is in the diet. Percent occurrence (PO) is frequency of occurrence divided by the amount of all occurrences of the prey items, and shows the importance of each item in the jaguarundi diet (Bisbal, 1986; Facure and Giaretta, 1996; Wang, 1999; Guerrero et al., 2002).

Differences in number of occurrences and prey occurrences in the wet and dry season were compared by chi-square tests using BioEstat 3.0 (Ayres et al., 2003) and the comparison between different studies was done with Cluster Analysis using Euclidean Distances, using STATISTICA 6.0 (StatSoft, 2001). Invertebrate preys were not included in the Cluster Analyses.

For the comparisons, the studies conducted at Serra da Capivara National Park (SCNP), Piaui State, northeast Brazil (Olmos, 1993); Santa Virgínia State Park (SVSP), São Paulo State, Brazil (Wang, 1999); Mogi Guaçu and Andirá Municipals (MGAM), southeast Brazil (Manzani and Monteiro-Filho, 1989); Companhia Vale do Rio Doce Forest Reserve (CVRDFR), Espirito Santo State, Brazil (Facure and Giaretta, 1996); Tenacatita, Jalisco State, Mexico (Guerrero et al., 2002); Cockscomb Basin Forest Reserve (CBFR), south-central Belize (Konecny, 1989) and two studies conduced on different localities in Venezuela (Bisbal, 1986; Mondolfi, 1986) were considered.

Average prey weights were obtained from the literature (Gans, 1980; Emmons and Feer, 1997; Eisenberg and Redford, 1999; Magalhães, 1999). Identified preys were classified according to weight in two groups: 1) below $1 \mathrm{~kg}$ and 2) more than $1 \mathrm{~kg}$. Since the largest identified bird was a tinamou (Crypturellus obsoletus) (Temminck, 1815) (Tinamidae), which can weigh almost $0.5 \mathrm{~kg}$, all birds, as well as snakes, were included in the first group. 
Food niche breadth (B), which estimates the specialisation degree of a species, was calculated after Levins (1969). It ranges from one to the number of categories used. To allow comparisons between studies with different number of prey categories, the standardised niche breadth $\left(\mathrm{B}_{\mathrm{sta}}\right)$ was calculated according to Colwell and Futuyma (1971). The values of $\mathrm{B}_{\text {sta }}$ range between 0 and 1 , a value closer to zero indicates a more specialised diet and closer to a more generalist one (Oliveira, 1994; Wang, 1999; Guerrero et al., 2002).

\section{Results}

From 128 samples of small felids found, only 26 (24 scats and 2 regurgitations) were identified as being from jaguarundi. Each jaguarundi sample was found on an average $22 \mathrm{~km}$ walk (in a total of $570.1 \mathrm{~km}$ walked). On average, two samples were collected each month. In four months (Nov., Dec. 2000, Mar., Oct. 2001), no sample was found and in two (Jan., Jul. 2001), the maximum of 6 was collected. All jaguarundi samples were found on dirt roads, none on trails. Most samples (62\%) were gathered near gallery forest, $12 \%$ near forest fragments, $12 \%$ near continuous forest and $14 \%$ in eucalyptus plantation.
The 26 jaguarundi samples had 19 identified food items, totalising 74 occurrences (Table 1). Grass appeared in three $(12 \%)$ samples in the wet season but was not included in the occurrences. All scats contained mammals, $62 \%$ birds, $58 \%$ invertebrates and $27 \%$ reptiles. The number of occurrences in a sample ranged from 1 (only rodents) to 6. Once, two individuals of the same species (Brucepattersonius soricinus) (Hershkovitz, 1998) (Muridae) occurred in one scat. Small mammals comprised $42.5 \%$ of the occurrences, followed by birds $(21 \%)$, reptiles (14\%) and larger mammals (3\%). Invertebrates made up $20 \%$ of occurrences (Table 1).

Rodents were the most prevalent prey (30\%) followed by undetermined birds (15.5\%), marsupials $(12.5 \%)$ and snakes (12\%, Table 1), with significant differences among them $\left(\chi^{2}=8.77, \mathrm{df}=3, \mathrm{p}=0.033\right)$. Furthermore, we found significant differences in number of occurrence between invertebrates, reptiles, birds, marsupials, medium-sized mammals and rodents $\left(\chi^{2}=\right.$ 19.24, $\mathrm{df}=5, \mathrm{p}=0.002)$, birds and small mammals $\left(\chi^{2}=\right.$ 4.79 , df $=1, \mathrm{p}=0.029)$, marsupials and rodents $\left(\chi^{2}=\right.$ $5.45, \mathrm{df}=1, \mathrm{p}=0.311)$ and rodents and reptiles $\left(\chi^{2}=4.5\right.$, $\mathrm{df}=1, \mathrm{p}=0.05)$. However, there was not significance between rodents and birds $\left(\chi^{2}=0.95, \mathrm{df}=1, \mathrm{p}=0.417\right)$,

Table 1. Percentage of occurrence, month and identification form of food items from jaguarundi scats and regurgitations at Pilar do Sul, southeast Brazil.

\begin{tabular}{|c|c|c|c|}
\hline Food items & $\begin{array}{c}\text { Percent } \\
\text { occurrence } \\
(\%)\end{array}$ & Month & $\begin{array}{l}\text { Identification } \\
\text { form }\end{array}$ \\
\hline
\end{tabular}

\section{Mammals}

Opossums - Didelphinae

Mouse opossums - Tribe Marmosini

Naked-tailed armadillo (Cabassous tatouay)

Brocket deer (Mazama sp.)

New World rats - Sigmodontinae

Rat (Brucepattersonius soricinus)

Rice rats (Oligoryzomys sp.)

Grass mouse (Thaptomys nigrita)

Lichtenstein, 1829)

Spiny rats - Echimyidae

Cavies - Caviidae

Non identified rodents

Birds

Tinamou (Crypturellus obsoletus)

Non-passerines

Order Passeriformes

Non identified birds

$$
\text { Reptiles }
$$

Snakes - Colubridae

Pit-vipers - Crotalinae

Tegu lizard (Tupinambis sp.)

Invertebrates

\begin{tabular}{cll}
5.5 & Jan., May, Aug., Sept. & hair \\
7 & Jan., June, July, Sept. & teeth \\
1.5 & Sept. & teeth and hair \\
1.5 & Apr. & hair \\
1.5 & June & molar teeth \\
5.5 & July, Aug. & molar teeth \\
2.5 & Aug., Sept. & molar teeth \\
2.5 & Jan., June & molar teeth \\
& & \\
1.5 & July & hair \\
1.5 & Jan. & hair \\
15 & Jan., Feb., May., June, July, Sept., Nov. & incisors, hair \\
& & \\
1.5 & June & claws \\
1.5 & Apr. & claws \\
2.5 & May, Sept. & claws \\
15.5 & Jan., Feb., May, June, July, Aug., Nov. & feather \\
& & \\
8 & Jan., June, July, Nov. & scales \\
4 & Jan., June, Aug. & scales \\
1.5 & Nov. & scales \\
20 & Jan., Feb., June, July, Aug., Sept., Nov. & fragments \\
100 & & \\
\hline & &
\end{tabular}


marsupials and birds $\left(\chi^{2}=1.96, \mathrm{df}=1, \mathrm{p}=0.230\right)$ and birds and reptiles $\left(\chi^{2}=1.39\right.$, df $\left.=1, \mathrm{p}=0.327\right)$.

Within rodents three families were identified, Muridae, Echimyidae and Caviidae (Table 1). Within snakes, pit-vipers and colubrids were recognised (Table 1). There was no seasonal significant difference in prey consumption (Figure $1 ; \chi^{2}=5.39, \mathrm{df}=11, \mathrm{p}=0.91$ ). Most prey (56 occurrences, $94.9 \%$ ) weighed below $1 \mathrm{~kg}$, and $3(5.1 \%)$ over $1 \mathrm{~kg}$ : Mazama (Cervidae), Tupinambis (Teiidae), and Cabassous tatouay (Desmarest, 1804) (Dasypodidade). The dietary niche breadth $(\mathrm{B}=4.8)$ and the standardised dietary niche breadth $\left(\mathrm{B}_{\text {sta }}=0.76\right)$ showed a generalist diet for jaguarundi in Pilar do Sul (Table 2.). The Cluster Analysis was conducted for a visual interpretation, since the sample sizes range over the studies. Its results showed that jaguarundi food habits from Pilar do Sul is more similar to the studies conducted by Facure and Giaretta (1996) and Gerrero et al. (2002) (Figure 2).

\section{Discussion}

The present study represents the largest sample of jaguarundi scats from Brazil, and the third from its geographic range (Table 2). Also, in Pilar do Sul, jaguarundi had the more diverse prey list (19 items), and at least three items recorded for the first time (brocket deer, naked-tailed armadillo and pit-vipers).

The jaguarundi diet at Pilar do Sul was similar to the diet observed at CVRDRF, another Brazilian
Atlantic Rainforest area (Facure and Giaretta 1996), and at Tenacatita, a tropical deciduous forest in Mexico (Guerrero et al., 2002), where small mammals were the most consumed prey, followed by birds and reptiles. However, at CVRDRF, marsupials and invertebrates were not consumed and at Tenacatita, jaguarundi preyed

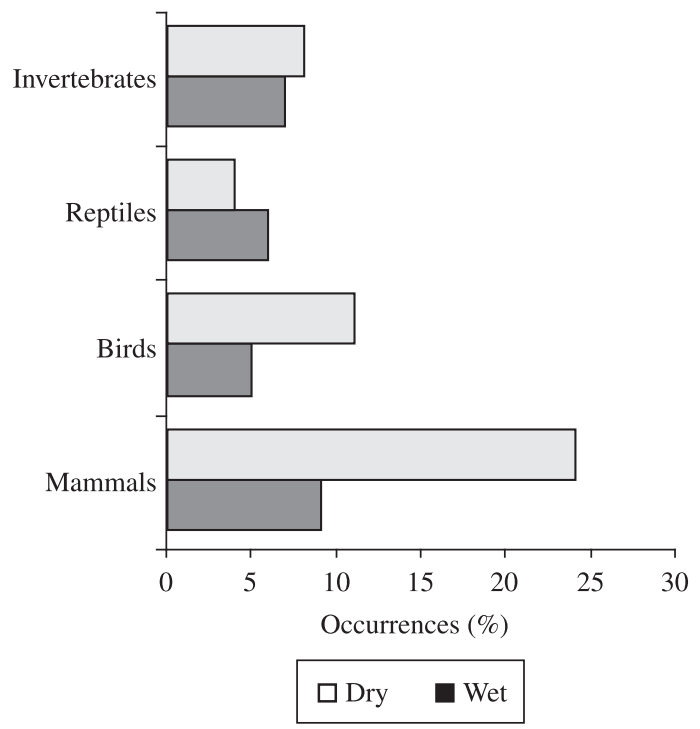

Figure 1. Seasonal occurrence of jaguarundi food items in Pilar do Sul, southeast Brazil.

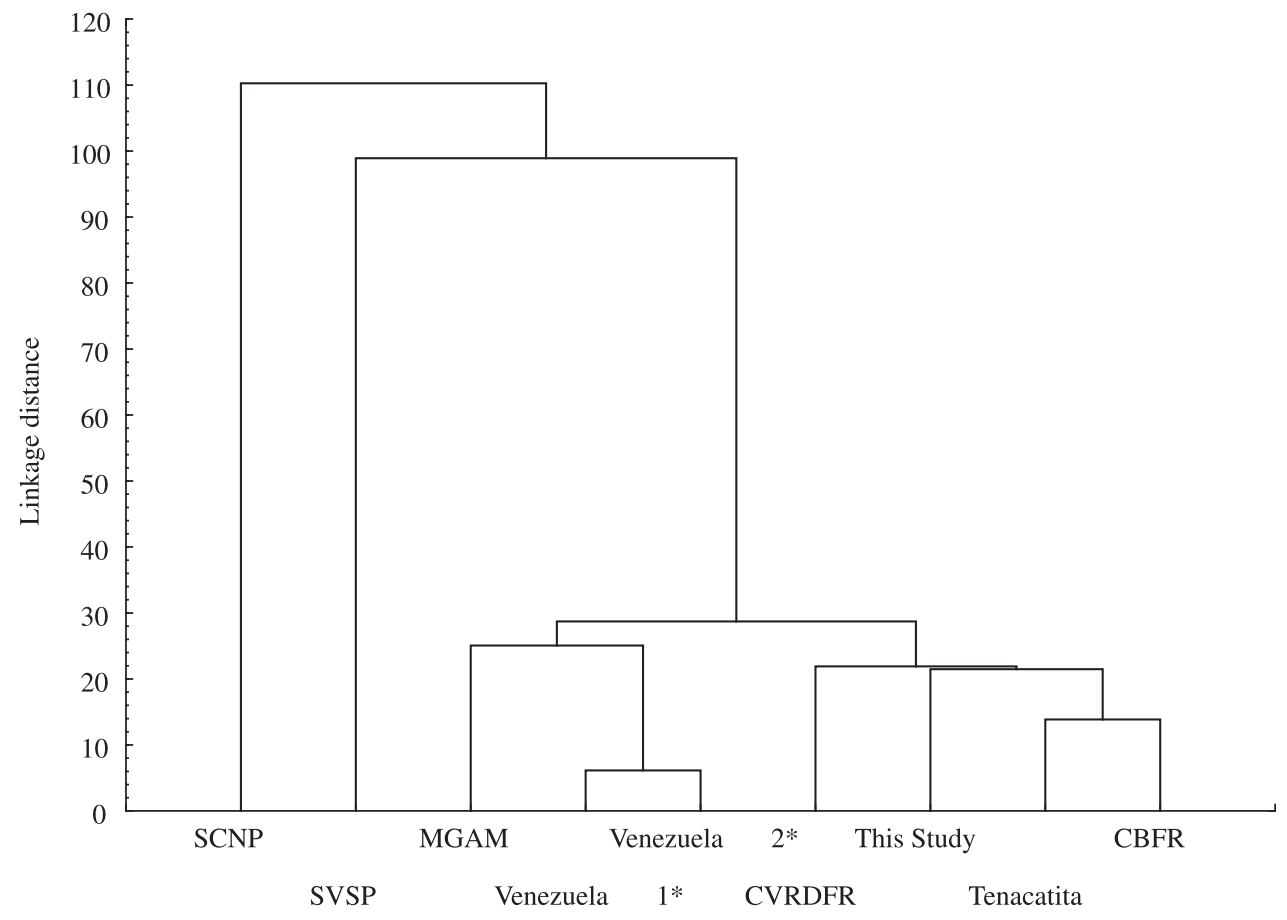

Figure 2. Similarity between the jaguarundi diet in different studies. Distances between sites are Euclidean distances. *Venezuela 1: Bisbal, 1986; Venezuela 2: Mondolfi, 1986. 


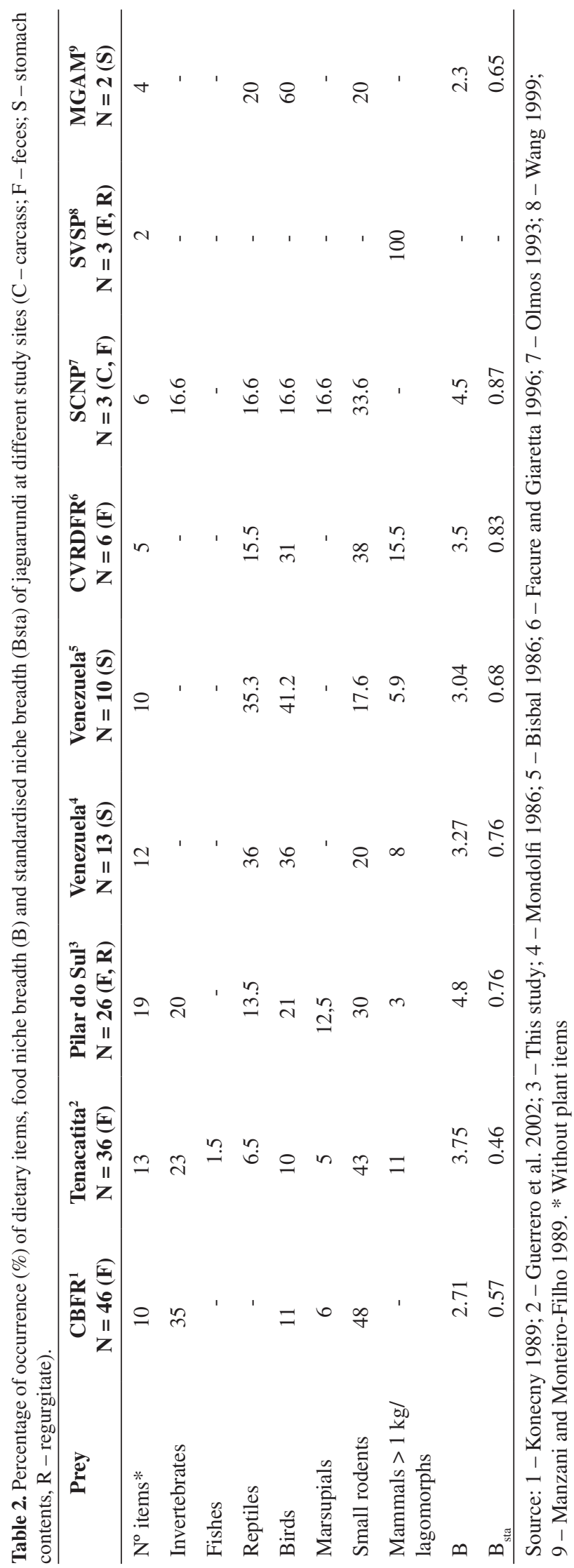


on fish (Table 2). Furthermore, by cluster analyses (Figure 2), we found that diet at Pilar do Sul is also closer to the study at CBFR, in south-central Belize (Konecny 1989).

As in the four other studies, rodents were the most important item in Pilar do Sul (Table 2). Larger mammals, naked-tailed-armadillo and brocket deer had low frequency at Pilar do Sul. Medium-sized mammals such as paca (Agouti paca) (Linnaeus, 1766) (Agoutidae) and brown-throated-three-toed-sloth (Bradypus variegatus) (Schinz, 1825) (Bradypodidae) were recorded elsewhere (Wang, 1999). The brocket deer in the jaguarundi diet at Pilar do Sul could be predation of young or carrion consumption; in the same month we recorded two deer in puma's diet (Rohe, 2002). The predation of brocket deer was already mentioned by Cabrera and Yeppes (1940), but they did not register it in the diet. The largest prey recorded for jaguarundi was cattle (Bos taurus) (Linnaeus, 1758) (Bovidae) in Mexico (Guerrero et al., 2002).

Birds appear in the jaguarundi diet in eight studies (Table 2), but were the most important item only in Venezuela (Bisbal 1986). Reptiles are also frequent (seven studies, Table 2), and appeared as the most frequent item in Venezuela (Mondolfi 1986, Table 2). Only two studies documented snakes (Facure and Giaretta, 1996; Guerrero et al., 2002). This is the first record of pit viper (Family Viperidae) consumption by a jaguarundi and the first with snakes more frequent than lizards.

In agreement with other studies of Neotropical small cats, nearly all species consumed were small, weighing less than $0.5 \mathrm{~kg}$ (Oliveira, 1994; Nowell and Jackson, 1996). Like jaguarundi, the prey species identified had predominantly diurnal and terrestrial habits (Oliveira, 1994, Nowell and Jackson, 1996; Emmons and Feer, 1997; Eisenberg and Redford, 1999), but crepuscular and nocturnal animals were also preyed upon (Sick 1993, Fonseca et al., 1996, Emmons and Feer, 1997; Eisenberg and Redford, 1999).

As in the study conducted by Mondolfi (1986) at different localities in Venezuela, jaguarundi at Pilar do Sul seem to have an intermediate diet (Table 2), more specialised than at CVRDFR (Facure and Giaretta, 1996) and at SCNP in northeastern Brazil (Olmos, 1993), and more generalised than at CBFR in Belize (Konecny 1989), MGAM in southeastern Brazil (Manzani and Monteiro-Filho, 1996), different localities in Venezuela (Bisbal, 1986) and at Tenacatita in Mexico (Guerrero et al., 2002).

Although having a diverse list of food items and range of dietary niche breaths, our data show that jaguarundi mainly prey on small vertebrates (mammals, birds or reptiles) and suggests that in tall tropical forests (or eucalypt plantations with native understory), it preys mostly on animals that come to the ground. Considering the fragmentation process in the Brazilian Atlantic Forest, more information about the diet of medium-sized carnivores, like $P$. yagouaroundi, and their role in this ecosystem are urgently needed. These studies are essen- tial to verify their action on environmental dynamics and for forest and species conservation.

Acknowledgements - This paper is part of the Bachelor's monograph by the senior author. We are grateful to Eucatex S.A. for financial and logistic support, especially to Marcelo Brisolla. We thank André Antunes for essential assistance in the field, Nivar Gobbi and CEA/UNESP for lab facilities, Alexandre Percequilho for rodent identifications, Elis Regina Ribas for snake identifications and Claudia R. Silva for sharing unpublished data. We are grateful to F. Lima, J. C. Motta-Junior and D. Munari for the comments on an earlier version of the manuscript, and W. W. Benson who kindly helped with the first English revision.

\section{References}

AYRES, M., AYRES-JUNIOR, M., AYRES, DL. and SANTOS, AAS., 2003. BioEstat: aplicações estatísticas nas áreas das ciências biomédicas. Belém: Sociedade Civil Mamirauá. 292 p.

BISBAL, FJ., 1986. Food habits of some Neotropical carnivores in Venezuela (Mammalia, Carnivora). Mammalia, vol. 50, no. 3, p. 329-339.

CABRERA, A. and YEPPES, J., 1940. Mamíferos SudAmericanos (Vida, Costumbres y Description). Buenos Aires: Historia natural Ediar, Compañía Argentina de Editores. 370 p.

COLWELL, RK. and FUTUYMA, DJ., 1971. On the Measurement of Niche Breadth and Overlap. Ecology, vol. 52, no. 4 , p. 567-576.

CROOKS, KR. and SOULÉ, ME., 1999. Mesopredator release and avifaunal extinctions in a fragmented system. Nature, vol. 400, p. 563-566.

EISENBERG, JF. and REDFORD, KH., 1999. Mammals of the neotropics: the central neotropics. Chicago: The University of Chicago Press. 609 p., vol. 3.

EMMONS, LH., 1987. Comparative feeding ecology of felids in a neotropical rainforest. Behavioral Ecology and Sociobiology, vol. 20 , no. 4 , p. 271-283.

EMMONS LH. and FEER, F., 1997. Neotropical Rainforest mammals: a field guide. 2 ed. Chicago: The University of Chicago Press. 307 p.

DIRZO, R. and MIRANDA, A., 1990. Contemporary neotropical defaunation and forest structure, function and diversity: a sequel to John Terborgh. Conservation Biology, vol. 4, no. 4, p. $444-447$

FACURE, KG. and GIARETTA, AA., 1996. Food habits of carnivores in a coastal Atlantic Forest of southeastern Brazil. Mammalia, vol. 60, no. 3, p. 499-502.

FONSECA, GAB. and ROBINSON, J., 1990. Forest size and structure: competitive and predatory effects on small mammal communities. Conservation Biology, vol. 53, no. 4, p. 265-294.

FONSECA, GAB., HERRMANN, G., LEITE, YLR., MITTERMEIER, RA., RYLANDS, AB., PATTON, JL., 1996. Lista anotada dos mamíferos do Brasil. Occasional Papers in Conservation Biology, vol. 4, p. 1-38

GANS, C., 1980. Répteis do mundo. São Paulo: USP. 159 p.

GUERRERO, S., BADII, MH., ZALAPA, SS. and FLORES, A., 2002. E. Dieta y nicho de alimentación del coyote, zorra 
gris, mapache y jaguarundi en un bosque tropical caducifolio de la costa sur del Estado e Jalisco. Acta Zoologica, vol. 86, p. 119-137.

KONECNY, MJ., 1989. Movement patterns and food habits of four sympatric carnivore species in Belize, Central America. In REDFORD, KH., EISENBERG, JF. (Ed.). Advances in neotropical mammalogy. Gainesville: Sandhill Crane Press. p. $243-264$

LEVINS, R., 1969. Evolution in changing environments. 2 ed. Princeton: Princeton University Press. 132 p.

MAGALHÃES, JC., 1999. As aves na Fazenda Barreiro Rico. São Paulo: Plêiade. 215 p.

MANZANI, PR. and MONTEIRO FILHO, EIA., 1996. Notes on the food habits of the jaguarundi, Felis yagouaroundi (Mammalia: Carnivora). Mammalia, vol. 53, no. 4, p. 659-660.

MONDOLFI, E., 1986. Notes on the biology and status of the small wild cats in Venezuela. In MILLER, SD., EVERET, DD. (Ed.). Cats of the world: biology, conservation and management. Washington: National Wildlife Federation's. p. 125-146.

NOWELL, K. and JACKSON, P. (Ed.)., 1996. Wild cats: status survey and conservation action plants. 1 ed. Gland: IUCN/SSC Cat Specialist Group. 382 p.

OLIVEIRA, TG., 1994. Neotropical cats: ecology and conservation. São Luiz: Universidade Federal do Maranhão. $220 \mathrm{p}$.

OLMOS, F., 1993. Notes on Food Habits of Brazilian "Caatinga" Carnivores. Mammalia, vol. 57, no. 1, p. 126-130.
ROHE, F., 2002. Hábitos Alimentares da Suçuarana (Puma concolor) (Linnaeus 1771) em Mosaico de Floresta Secundária e reflorestamento de Eucaliptus saligna, em Mata Atlântica, no Município de Pilar do Sul - SP. São Paulo: USP. 83 p. [Monografia].

SICK, H., 1993. Birds in Brazil: a natural history. Princeton: Princeton University Press. 703p.

STATSOFT, 2001. Statistica. Version 6. Available from: www. statsoft.com. Access in: June 2006.

TERBORGH, J., 1990. The role of felid predators in Neotropical Forests. Vida Silvestre Neotropical, vol. 2, no. 2, p. 3-5.

TERBORGH, J., ESTES, JA., PAQUET, P., RALLS, K., BOYLD-HEGER, D., MILLER, BJ., 1999. The role of top carnivores in regulating terrestrial ecosystems. In SOULÉ, ME. and TERBORGH, J. (Ed.). Continental conservation: scientific foundations of regional reserve networks. Washington: Island Press. p. 39-64.

TERBORGH, J., LOPEZ, L., NUÑEZ, P., RAO, M., SHAHABUDDIN, G., ORIHUELA, G., 2001. Ecological meltdown in predator-free forest fragments. Science, vol. 294, no. 5548 , p. $1923-1926$.

XIMENES, A., 1982. Notas sobre felidos neotropicales, VIII Observaciones sobre el contenido estomacal y el comportamiento alimentar de diversas espécies de felinos. Revista Nordestina de Biologia, vol. 5, no. 1, p. 89-91.

WANG, E. 1999. O que comem os felídeos em uma área de Mata Atlântica?. Rio Claro: UNESP. [Dissertação de Mestrado]. 